Johannes Rüberg

\title{
Die Preisbestimmung in der Telekommunikation
}

Ein rechtshistorischer Vergleich der Preissetzungsverfahren des deutschen und USamerikanischen Fernmeldewesens von den Anfängen bis zum Beginn der Liberalisierung des Marktes

[Determining Telecommunication Prices. German and US Pricing Methods Since Market Liberalization.]

Published in German.

Johannes Rüberg's legal-historical comparison examines the development and mechanisms of price determination in

JOHANNES RÜBERG

Die Preisbestimmung in der Telekommunikation
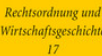

Mohr Siebeck

2017. XVI, 271 pages. ROWG 17

ISBN 978-3-16-154550-4

cloth $114,00 €$

ISBN 978-3-16-160622-9

eBook PDF $114,00 €$
Germany and the USA, revealing the differences and similarities in institutional pricing structure in these highly dynamic

telecommunications markets.

Johannes Rüberg Geboren 1983; Studium der Rechtswissenschaften an den Universitäten Passau und Bonn; Mitarbeiter des vom Bundesministerium für Bildung und Forschung geförderten interdisziplinären Forschungsprojekts »Gestaltung der Freiheit - Regulierung von Wirtschaft zwischen historischer Prägung und Normierung«; 2014 Assessorexamen im OLG Bezirk Düsseldorf; seit 2015 Rechtsanwalt in Düsseldorf.

\section{Order now:}

https://www.mohrsiebeck.com/en/book/die-preisbestimmung-in-der-telekommunikation-9783161545504?no_cache=1 order@mohrsiebeck.com

Phone: $+49(0) 7071-923-17$

Fax: +49 (0)7071-51104 